\title{
Dietary factors in carcinoma of the stomach: A study of 100 cases and 200 controls
}

\author{
E. D. ACHESON AND R. DOLL \\ From the Nuffield Department of Medicine, Radcliffe Infirmary, Oxford, the Central Middlesex Hospital, \\ and the Medical Research Council's Statistical Research Unit
}

EDITORIAL SYNOPSIS The declining mortality from carcinoma of the stomach in western countries and the big variations in incidence between countries makes it likely that there are environmental factors concerned in this disease. This study is an attempt to define dietary differences but no convincing differences of probable aetiological importance were discovered.

Several features of the epidemiology of carcinoma of the stomach suggest that its incidence is determined more by environmental than by genetic factors. Among these are the geographical distribution of the disease, its recent decrease in incidence in many countries, and its predilection for the lower social strata (Doll, 1958; Haenszel, 1958). The most obvious explanation is that the incidence is largely determined by dietetic factors. This possibility has been investigated several times with inconclusive results (Stocks and Karn, 1933; Herbert and Bruske, 1936; Stocks, 1957; Segi, Fukushima, Fujisaku, Kurihara, Saito, Asano, and Kamoi, 1957; Wynder, Kmet,Dungal, and Segi,1963). It is, however,extremely difficult to obtain dietetic histories that provide an accurate reflection of past eating habits and it seemed of interest to study a fresh group of patients with special emphasis on the repeatability of the data.

\section{MATERIAL AND METHOD}

One hundred consecutive in-patients under the age of 75 years in whom a firm diagnosis of carcinoma of the stomach had been made were, therefore, interrogated about their dietary habits by trained interviewers using a standard questionnary. Each patient was matched for age (within five years) and sex with two other in-patients of the same hospital, excluding only patients known to have other diseases of the stomach or duodenum. These control patients were interviewed concurrently with the carcinoma patients.

At the beginning of the interview it was explained to the patients that the study was concerned with their dietary habits before the onset of symptoms of the present illness. Thirty-four confirmed cases and 68 controls were interviewed at the Radcliffe Infirmary by one interviewer; 66 confirmed cases and 132 controls at the Central Middlesex Hospital or at St. James's Hospital, Balham, by a second interviewer. Patients were inter- viewed as soon as a provisional diagnosis was made. The provisional diagnosis was, however, confirmed in the great majority of cases, so that the interviewer nearly always knew the correct diagnosis at the time of interview. To study the reproducibility of the answers 63 patients were interrogated again, using the same questionnary, after an interval of three to six months.

The questionnary was a modification of one prepared by Haenszel (personal communication) for use in international studies. In addition to general questions about race, religion, age, marital state, and occupation, each patient was asked: 1 Which had been the main meal of the day; 2 the customary time taken in minutes to eat the main meal; 3 the frequency with which 48 different items of food had been eaten, including bread, various types of meat, fish (fresh, dried, smoked, and tinned considered separately), eggs, a wide range of vegetables and fruits, tomato juice, sauce, and pickles; 4 the frequency with which milk, coffee, tea, cocoa, bottled soft drinks, beer, wine, and spirits had been drunk; 5 the spread used most often on bread, $(a)$ recently, and $(b)$ before the Second World War; 6 the way or ways in which each item in (3) had been served (roasted, fried, baked, grilled, boiled, raw, or pickled); 7 the temperature at which cooked food was eaten; 8 the temperature at which tea and coffee were drunk. Women were asked in addition, 9, which fat they used most often for cooking; 10 what metal their saucepans were made of; and, 11, what metal their frying pans were made of. For each of these last questions the answers were recorded separately for (a) now and (b) before the war.

\section{RESULTS}

REPRODUCIBILITY OF THE ANSWERS Sixty-three patients, including 10 with cancer of the stomach and 53 controls, were selected for re-interview three months later. These patients were a systematic sample of those who lived within a convenient distance of the hospitals concerned. The paucity of 
cancer cases was due to the fact that within three months many of them were already dead or too ill to interview.

Reproducibility was assessed by comparing the patients' answers to each question on the two occasions. The questions were classified in two groups: 1 Those in which the answer was qualitative and the two answers either agreed or disagreed (questions $1,5,8,10$, and 11); 2 those in which the answer was quantitative. For example, there were five possible answers to questions of the type, How often did you eat fish? Examples are shown in Table III. For this type of question the answers on the two occasions were classified as (a) identical, (b) within one degree in either direction, or (c) separated by more than one degree.

The reproducibility of the 'frying indices' (see below) was studied by correlating the two indices obtained for each case (see Figure).

The reproducibility of the answers to the qualitative questions is shown in Table 1. The majority of patients gave consistent answers to question 1 (which had been the main meal of the day) and to questions $5 \mathrm{a}, 10 \mathrm{a}$, and 11a (what spread on bread, what type of saucepan, and what type of frying pan had been used recently). On the other hand the answers to questions concerning these habits before the war $(5 \mathrm{~b}, 10 \mathrm{~b}$, and $11 \mathrm{~b})$ were so inconsistent that they suggest that the patients were guessing at random. The questions concerning the type of cooking fat used (questions 9a and b) both recently and before the war were also both answered in an inconsistent manner.

The reproducibility of the answers to the 'quantitative' questions is shown in Table II. The consistency of answers to question 2 (the time taken to eat the main meal) was poor. Those dealing with the temperature of cooked food (question 7) and of tea and coffee (question 8) were more reproducible; thus more than $90 \%$ of the completed pairs of answers were identical or within one degree in either direction. Table II also shows accumulated figures for the reproducibility of the answers to the questions concerning the frequency of taking 48 types of food and eight types of drink. Ninety per cent of the answers were identical or within one degree in either direction.

As far as individual items were concerned the

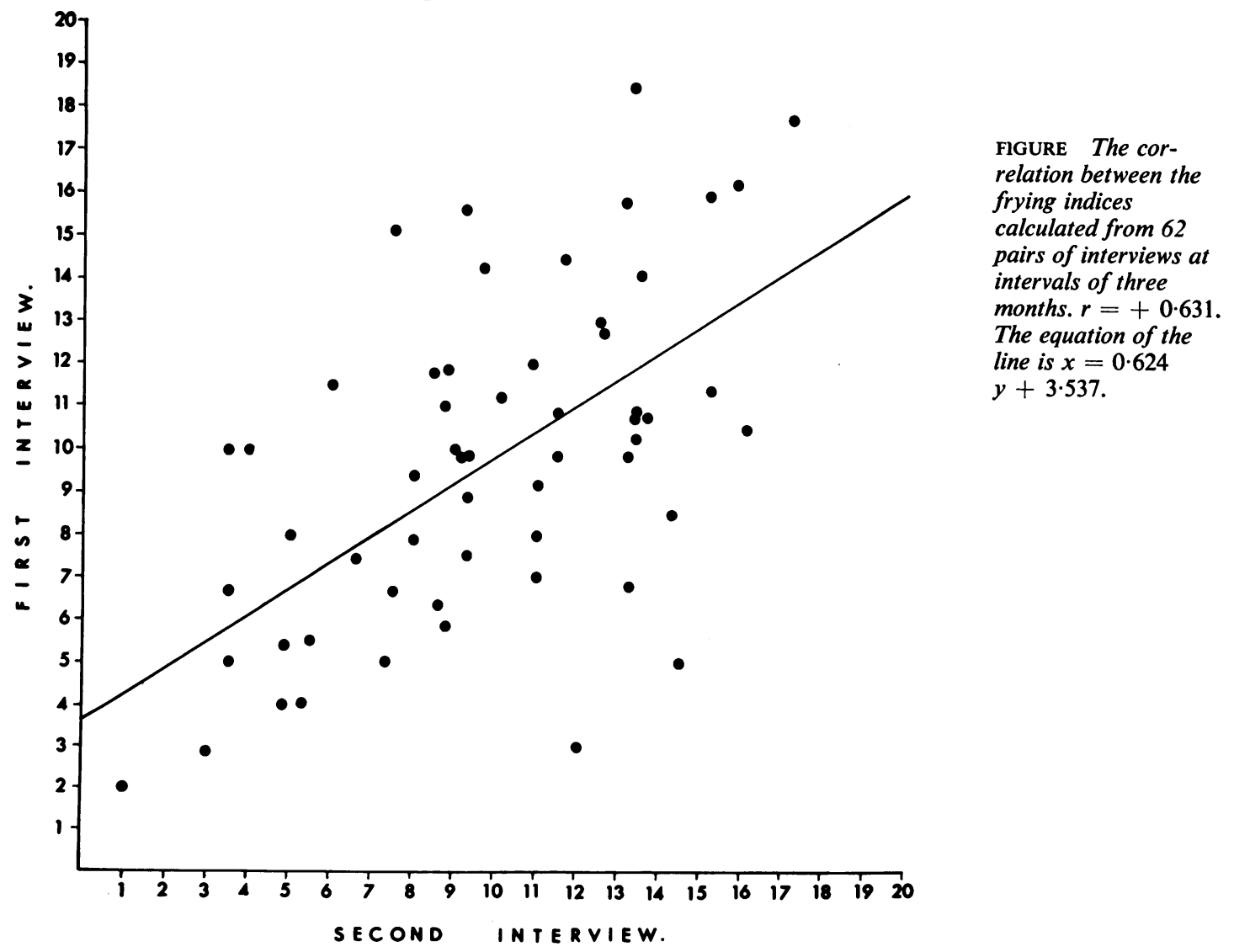


TABLE I

REPRODUCIBILITY OF THE ANSWERS TO QUALITAT'VE QUESTIONS

\begin{tabular}{|c|c|c|c|c|c|}
\hline \multirow[t]{2}{*}{ Question No. } & \multirow{2}{*}{$\begin{array}{l}\text { No. of Alternative } \\
\text { Answers to Each Question }\end{array}$} & \multicolumn{3}{|c|}{ No. of Pairs of Answers (percentage of total in brackets) } & \multirow[t]{2}{*}{ No. of Subjects } \\
\hline & & Complete Agreement & $\begin{array}{l}\text { Partial }{ }^{1} \text { or Complete } \\
\text { Disagreement }\end{array}$ & $\begin{array}{l}\text { Incomplete or Not } \\
\text { Applicable }\end{array}$ & \\
\hline $\begin{array}{c}1 \\
5 \mathrm{a} \\
5 \mathrm{~b} \\
9 \mathrm{a} \\
9 \mathrm{~b} \\
10 \mathrm{a} \\
10 \mathrm{~b} \\
11 \mathrm{a} \\
11 \mathrm{~b}\end{array}$ & $\begin{array}{l}3 \\
2 \\
2 \\
7 \\
7 \\
7 \\
3 \\
3 \\
3 \\
3\end{array}$ & $\begin{array}{l}49(77 \cdot 7) \\
46(73 \cdot 0) \\
23(36 \cdot 5) \\
32(50 \cdot 7) \\
20(41 \cdot 6) \\
37(77 \cdot 0) \\
21(43 \cdot 7) \\
30(62 \cdot 5) \\
16(33 \cdot 3)\end{array}$ & $\begin{array}{r}14(22 \cdot 0) \\
3(4 \cdot 7) \\
29(46 \cdot 0) \\
16(33 \cdot 3) \\
18(37 \cdot 5) \\
11(22 \cdot 9) \\
21(43 \cdot 7) \\
18(37 \cdot 5) \\
25(52 \cdot 0)\end{array}$ & $\begin{array}{r}0(0.0) \\
14(22 \cdot 2) \\
11(17 \cdot 5) \\
0(0.0) \\
10(20 \cdot 8) \\
0(0.0) \\
6(12 \cdot 5) \\
0(0.0) \\
7(14 \cdot 6)\end{array}$ & $\begin{array}{l}63 \\
63 \\
63 \\
48 \text { (women only) } \\
48 \text { (women only) } \\
48 \text { (women only) } \\
48 \text { (women only) } \\
48 \text { (women only) } \\
48 \text { (women only) }\end{array}$ \\
\hline
\end{tabular}

TABLE II

REPRODUCIBILITY OF THE ANSWERS TO QUANTITATIVE QUESTIONS

\begin{tabular}{|c|c|c|c|c|c|c|}
\hline \multirow[t]{2}{*}{ Question No. } & \multirow{2}{*}{$\begin{array}{l}\text { No. of Alternative } \\
\text { Answers to Each } \\
\text { Question }\end{array}$} & \multicolumn{4}{|c|}{ No. of Pairs of Answers (percentage of total in brackets) } & \multirow{2}{*}{$\begin{array}{l}\text { Total No. of } \\
\text { Pairs of Answers }\end{array}$} \\
\hline & & Identical & $\begin{array}{l}\text { Within one Grade } \\
\text { of One Another }\end{array}$ & $\begin{array}{l}\text { Separated by More } \\
\text { than One Grade }\end{array}$ & $\begin{array}{l}\text { Incomplete or } \\
\text { not Applicable }\end{array}$ & \\
\hline $\begin{array}{l}2 \\
3^{1} \\
4^{2} \\
7 \\
8\end{array}$ & $\begin{array}{l}5 \\
5 \\
5 \\
4 \\
5\end{array}$ & $\begin{array}{r}25(39 \cdot 6) \\
1,759(58 \cdot 2) \\
303(60 \cdot 1) \\
41(65 \cdot 0) \\
57(45 \cdot 2)\end{array}$ & $\begin{array}{c}29(46.0) \\
929(30 \cdot 7) \\
152(30 \cdot 2) \\
20(31 \cdot 7) \\
38(30 \cdot 2)\end{array}$ & $\begin{array}{r}9(14.2) \\
281(9.3) \\
29(5.8) \\
2(3.2) \\
5(4.0)\end{array}$ & $\begin{array}{r}0(0.0) \\
55(1.8) \\
20(4.0) \\
0(0.0) \\
26(20.6)\end{array}$ & $\begin{array}{r}63 \\
3,087 \\
504 \\
63 \\
126\end{array}$ \\
\hline
\end{tabular}

148 items summed. 28 items summed.

reproducibility depended to some extent on the frequency with which the food was eaten. Thus the questions about foods which the majority of patients 'never' ate, or ate several times weekly at least were answered in a more consistent manner than questions about those eaten relatively infrequently. Questions about the following foods were answered by at least $95 \%$ of the patients in an identical manner or within one degree in either direction: Sauerkraut and sweet corn (items very rarely eaten by cases or controls); potatoes, brussels sprouts, runner beans, lamb, and eggs (items eaten by the majority more than once a week); and ham and poultry. The least consistently answered questions (less than $75 \%$ of answers within one degree) were those dealing with dried/salted fish, bananas, tomato sauce, other sauce, and broad beans.

The figure shows the correlation between the frying indices estimated from data obtained at the two interviews in the 63 patients. A significant degree of correlation is present $(r=+0.63 ; 95 \%$ confidence limits, 0.46 and 0.77 ).

COMPARISON BETWEEN CASES AND CONTROLS With a few exceptions referred to below the results of the survey were negative. The answers to questions (1) and (2) were remarkably similar in both cases and controls. In Table III are shown the answers to 12 of the 48 questions relating to the frequency with which individual items of food were eaten. The general pattern of reply varied widely according to the type of foodstuff, but there was no significant difference in pattern between the two groups of patients for any of the items. The remaining 36 questions, to all of which cases and controls responded in a similar manner, are listed in the Appendix.

The frequency with which milk, tea, coffee, cocoa, soft drinks, beer, wine, and spirits were reported to have been drunk was also closely similar in cases and controls.

Indices were obtained of the frequency with which various methods of cooking were reported to have been employed. Weights (0-4) were assigned to the frequency with which items of cooked food had been eaten; if it was indicated that a given method of cooking was the only one employed the whole weight was assigned to that method; thus, if bacon had been taken daily and was always fried, the weight assigned to the 'frying' index was $\mathbf{4}$ units. If potatoes were taken daily, sometimes fried and sometimes boiled, one half of the weight ( 2 units) was assigned to each index. Values were derived in this way for all items of cooked food and were then summed. In this, way, frying, roasting, pickling, and boiling indices were compared in cases and controls (Table IV). Contrary to expectation the frying index was higher (frying was reported as a commoner method of cooking) in controls than in cases. There were no other material differences.

In Table $\mathrm{V}$ are displayed the reported preferences 
TABLE III

ANSWERS TO 12 OF 49 QUESTIONS RELATING TO INDIVIDUAL ITEMS OF FOOD IN CASES AND CONTROLS

\begin{tabular}{|c|c|c|c|c|c|}
\hline Never (\%) & $\begin{array}{l}\text { Monthly or } \\
\text { Less }(\%)\end{array}$ & $\begin{array}{l}\text { More than } \\
\text { Monthly to } \\
\text { Weekly (\%) }\end{array}$ & $\begin{array}{l}\text { Two-Six Days } \\
\text { per Week }(\%)\end{array}$ & Daily (\%) & $\begin{array}{c}\text { Not Stated }(\%) \text { Reproducibility }{ }^{1}(\%) \\
(\%)\end{array}$ \\
\hline
\end{tabular}

\begin{tabular}{|c|c|c|c|c|c|c|c|c|}
\hline Beef & $\begin{array}{l}\text { Cases } \\
\text { Controls }\end{array}$ & $\begin{array}{l}3.0 \\
1.5\end{array}$ & $\begin{array}{l}5 \cdot 0 \\
3 \cdot 0\end{array}$ & $\begin{array}{l}22 \cdot 0 \\
24 \cdot 5\end{array}$ & $\begin{array}{l}70 \cdot 0 \\
70 \cdot 5\end{array}$ & $\begin{array}{l}0.0 \\
0.5\end{array}$ & - & 95 \\
\hline Tinned meat & $\begin{array}{l}\text { Cases } \\
\text { Controls }\end{array}$ & $\begin{array}{l}29 \cdot 0 \\
35 \cdot 5\end{array}$ & $\begin{array}{l}42.0 \\
33 \cdot 5\end{array}$ & $\begin{array}{l}24 \cdot 0 \\
24 \cdot 5\end{array}$ & $\begin{array}{l}5.0 \\
6.5\end{array}$ & - & - & 89 \\
\hline Fresh fish & $\begin{array}{l}\text { Cases } \\
\text { Controls }\end{array}$ & $\begin{array}{r}8 \cdot 0 \\
10 \cdot 0\end{array}$ & $\begin{array}{l}12 \cdot 0 \\
13 \cdot 0\end{array}$ & $\begin{array}{l}59 \cdot 0 \\
63 \cdot 0\end{array}$ & $\begin{array}{l}21.0 \\
14.0\end{array}$ & - & - & 92 \\
\hline Dried/salted fish & $\begin{array}{l}\text { Cases } \\
\text { Controls }\end{array}$ & $\begin{array}{l}38 \cdot 0 \\
32 \cdot 0\end{array}$ & $\begin{array}{l}34 \cdot 0 \\
38 \cdot 0\end{array}$ & $\begin{array}{l}25 \cdot 0 \\
28 \cdot 0\end{array}$ & $\begin{array}{l}3.0 \\
1.5\end{array}$ & - & $\overline{0.5}$ & 76 \\
\hline Smoked fish & $\begin{array}{l}\text { Cases } \\
\text { Controls }\end{array}$ & $\begin{array}{l}34 \cdot 0 \\
32 \cdot 0\end{array}$ & $\begin{array}{l}36 \cdot 0 \\
41 \cdot 5\end{array}$ & $\begin{array}{l}27 \cdot 0 \\
23 \cdot 5\end{array}$ & $\begin{array}{l}3.0 \\
2.5\end{array}$ & $\overline{0.5}$ & - & 87 \\
\hline Tinned fish & $\begin{array}{l}\text { Cases } \\
\text { Controls }\end{array}$ & $\begin{array}{l}38.0 \\
31.5\end{array}$ & $\begin{array}{l}26 \cdot 0 \\
39 \cdot 0\end{array}$ & $\begin{array}{l}35.0 \\
26.5\end{array}$ & $\begin{array}{l}1.0 \\
3.0\end{array}$ & $\overline{-}$ & $\overline{-}$ & 94 \\
\hline Parsnips & $\begin{array}{l}\text { Cases } \\
\text { Controls }\end{array}$ & $\begin{array}{l}40 \cdot 0 \\
32 \cdot 0\end{array}$ & $\begin{array}{l}18 \cdot 0 \\
17 \cdot 5\end{array}$ & $\begin{array}{l}29 \cdot 0 \\
26 \cdot 5\end{array}$ & $\begin{array}{l}13 \cdot 0 \\
23 \cdot 5\end{array}$ & $\overline{0.5}$ & $\overline{-}$ & 86 \\
\hline Potatoes & $\begin{array}{l}\text { Cases } \\
\text { Controls }\end{array}$ & $\begin{array}{l}1.0 \\
1.5\end{array}$ & $\begin{array}{l}1.0 \\
0.5\end{array}$ & $\begin{array}{l}1.0 \\
2.0\end{array}$ & $\begin{array}{l}18.0 \\
13.5\end{array}$ & $\begin{array}{l}79.0 \\
82.5\end{array}$ & $\overline{-}$ & 97 \\
\hline Oranges & $\begin{array}{l}\text { Cases } \\
\text { Controls }\end{array}$ & $\begin{array}{l}10.0 \\
16.0\end{array}$ & $\begin{array}{l}24.0 \\
16.5\end{array}$ & $\begin{array}{l}17.0 \\
21.0\end{array}$ & $\begin{array}{l}31.0 \\
30.0\end{array}$ & $\begin{array}{l}18.0 \\
16.5\end{array}$ & - & 87 \\
\hline Tomatoes & $\begin{array}{l}\text { Cases } \\
\text { Controls }\end{array}$ & $\begin{array}{l}8.0 \\
9.0\end{array}$ & $\begin{array}{l}4.0 \\
7.0\end{array}$ & $\begin{array}{l}25.0 \\
21.0\end{array}$ & $\begin{array}{l}50.0 \\
51.0\end{array}$ & $\begin{array}{l}13.0 \\
12.0\end{array}$ & $=$ & 84 \\
\hline Pickles & $\begin{array}{l}\text { Cases } \\
\text { Controls }\end{array}$ & $\begin{array}{l}31.0 \\
24.5\end{array}$ & $\begin{array}{l}10.0 \\
17.5\end{array}$ & $\begin{array}{l}17.0 \\
16.5\end{array}$ & $\begin{array}{l}10.0 \\
14.0\end{array}$ & $\begin{array}{l}1.0 \\
1.0\end{array}$ & $\begin{array}{l}31.0 \\
26.5\end{array}$ & 81 \\
\hline Tinned fruit & $\begin{array}{l}\text { Cases } \\
\text { Controls }\end{array}$ & $\begin{array}{l}8.0 \\
9 \cdot 5\end{array}$ & $\begin{array}{l}16.0 \\
13.0\end{array}$ & $\begin{array}{l}55.0 \\
52.5\end{array}$ & $\begin{array}{l}19 \cdot 0 \\
24 \cdot 0\end{array}$ & $\begin{array}{l}1.0 \\
0.5\end{array}$ & $\begin{array}{l}1.0 \\
0.5\end{array}$ & 94 \\
\hline
\end{tabular}

'Proportion of 63 patients whose answers on the second occasion fell within one grade of that on the first occasion.

TABLE IV

COOKING INDICES IN CASES AND CONTROLS

\begin{tabular}{|c|c|c|c|c|c|}
\hline & \multicolumn{2}{|l|}{ Cases } & \multicolumn{2}{|l|}{ Controls } & \\
\hline & Mean & Standard Error & Mean & Standard Error & \\
\hline $\begin{array}{l}\text { Frying index } \\
\text { Roasting index } \\
\text { Boiling index } \\
\text { Pickling index }\end{array}$ & $\begin{array}{r}7 \cdot 90 \pm \\
4 \cdot 73 \pm \\
30 \cdot 33 \pm \\
1.35 \pm\end{array}$ & $\begin{array}{l}0.42 \\
0 \cdot 15 \\
0 \cdot 64 \\
0 \cdot 18\end{array}$ & $\begin{array}{r}8.90 \pm \\
4.88 \pm \\
30.40 \pm \\
1.64 \pm\end{array}$ & $\begin{array}{l}0.30 \\
0 \cdot 11 \\
0 \cdot 51 \\
0 \cdot 14\end{array}$ & $\begin{array}{l}{ }^{1} p=0.05 \\
p>0.05 \\
p>0.05 \\
p>0.05\end{array}$ \\
\hline
\end{tabular}

${ }^{1} \mathrm{t}=1.94$

TABLE V

REPORTED PREFERENCES OF CASES AND CONTROLS IN RESPECT OF TEMPERATURES OF COOKED FOOD, TEA, AND COFFEE

\begin{tabular}{|c|c|c|c|c|c|c|c|}
\hline \multirow[t]{2}{*}{ Type of Food } & \multirow[t]{2}{*}{ Patients } & \multicolumn{4}{|c|}{ Percentage of Patients with Preference for Food } & \multirow{2}{*}{$\begin{array}{l}\text { Not Applicable } \\
\text { or Not Stated }\end{array}$} & \multirow{2}{*}{$\begin{array}{l}\text { Total No. of } \\
\text { Patients }\end{array}$} \\
\hline & & Very Hot & Hot & Warm & Cool & & \\
\hline Cooked food ${ }^{1}$ & $\begin{array}{l}\text { Gastric cancer } \\
\text { Controls }\end{array}$ & $\begin{array}{l}18 \cdot 0 \\
23 \cdot 0\end{array}$ & $\begin{array}{l}47 \cdot 0 \\
60 \cdot 5\end{array}$ & $\begin{array}{l}31 \cdot 0 \\
15 \cdot 0\end{array}$ & $\begin{array}{l}4 \cdot 0 \\
1 \cdot 5\end{array}$ & - & $\begin{array}{l}100 \\
200\end{array}$ \\
\hline Tea $^{1}$ & $\begin{array}{l}\text { Gastric cancer } \\
\text { Controls }\end{array}$ & $\begin{array}{l}18 \cdot 0 \\
27 \cdot 5\end{array}$ & $\begin{array}{l}39 \cdot 0 \\
46 \cdot 0\end{array}$ & $\begin{array}{l}38 \cdot 0 \\
19 \cdot 0\end{array}$ & $\begin{array}{l}2 \cdot 0 \\
1 \cdot 0\end{array}$ & $\begin{array}{r}3 \\
13\end{array}$ & $\begin{array}{l}100 \\
200\end{array}$ \\
\hline Coffee $^{1}$ & $\begin{array}{l}\text { Gastric cancer } \\
\text { Controls }\end{array}$ & $\begin{array}{l}14 \cdot 0 \\
22 \cdot 0\end{array}$ & $\begin{array}{l}36 \cdot 0 \\
38 \cdot 0\end{array}$ & $\begin{array}{l}28 \cdot 0 \\
13 \cdot 0\end{array}$ & $\begin{array}{l}3 \cdot 0 \\
2 \cdot 0\end{array}$ & $\begin{array}{l}19 \\
50\end{array}$ & $\begin{array}{l}100 \\
200\end{array}$ \\
\hline
\end{tabular}

${ }^{1} \mathrm{p}<0.01$. D.F. $=2$.

of cases and controls in respect of the temperature of cooked food, tea, and coffee. A striking difference is seen to be consistent to all three items, namely, that the cancer patients stated that they liked to take their food and drink cooler than the controls.

No difference was found between the type of spread used on bread or its duration of use, or between the types of cooking utensil used since the 
TABLE VI

TYPES OF COOKING UTENSIL REPORTED USED SINCE THE WAR (WOMEN ONLY) COMPARED

\begin{tabular}{|c|c|c|c|c|c|c|}
\hline \multirow[t]{2}{*}{ Utensil } & \multirow[t]{2}{*}{ Patients } & \multicolumn{4}{|c|}{ Percentage of Patients Reported Using: } & \multirow{2}{*}{$\begin{array}{l}\text { Total No. of } \\
\text { Patients }\end{array}$} \\
\hline & & Aluminium & Iron & Other 1 & Unknown etc. & \\
\hline Frying pans & $\begin{array}{l}\text { Gastric cancer } \\
\text { Controls }\end{array}$ & $\begin{array}{r}51 \cdot 6 \\
45 \cdot 2\end{array}$ & $\begin{array}{c}16 \cdot 1 \\
21 \cdot 0\end{array}$ & $\begin{array}{l}25 \cdot 8 \\
30 \cdot 6\end{array}$ & $\begin{array}{l}6 \cdot 4 \\
3 \cdot 1\end{array}$ & $\begin{array}{l}31 \\
62\end{array}$ \\
\hline Saucepans & $\begin{array}{l}\text { Gastric cancer } \\
\text { Controls }\end{array}$ & $\begin{array}{l}57 \cdot 5 \\
69 \cdot 6\end{array}$ & $\begin{array}{l}0.0 \\
0.0\end{array}$ & $\begin{array}{l}39 \cdot 4 \\
27 \cdot 3\end{array}$ & $\begin{array}{l}3 \cdot 0 \\
3 \cdot 0\end{array}$ & $\begin{array}{l}33 \\
66\end{array}$ \\
\hline
\end{tabular}

${ }^{1}$ Enamel, enamelled iron, stainless steel, tinned steel, heavy steel, Pyrex.

war (Table VI). The reproducibility study (Table I) shows that the patients were unable to give dependable information about these habits before the war.

\section{DISCUSSION}

Within the limitations of the method used the study has failed to reveal any differences in the type or quantity of foods, beverages, or alcoholic drinks taken by cases and controls. In view of the geographical distribution of carcinoma of the stomach special attention was paid in the questionnary to fish products (Dungal, 1956 and 1961), potatoes (Wynder et al., 1963), and citrus fruits and green vegetables (Haenszel, 1958), but no differences in intake were observed. These results agree with those of Wynder et al. who used a similar technique to compare the dietary habits of groups of cases and controls in Japan, Iceland, and Slovenia (high incidence) and New York (low incidence), and whose results were also entirely negative.

The positive findings in this study, which are limited to the temperature at which food and drinks were preferred and the quantity of fried food taken, are difficult to explain and are contrary to current hypotheses. The cancer patients stated that they preferred to eat their food and to drink their tea and coffee cooler than the controls. The size of the shifts in these distributions and their consistency is impressive, and they are most unlikely to be chance fluctuations. Moreover, similar results were obtained by Segi et al. (1957). Yet Edwards and Edwards (1956) found that persons with histologically proved superficial or atrophic gastritis (who are presumed to be at greater risk of developing gastric cancer) chose to drink fluids at a higher temperature than did normal controls. Another unexpected result was the significantly lower frying indices in the cancer patients than in controls, a finding contrary to that of Stocks (1957) in ncrth Wales. It is possible that both these phenomena reflect the fact that a higher proportion of the cancer patients had gastric symptoms at the time of interview than did the controls and responded differently to these questions for this reason. Against this explanation it should be noted that: 1 The interviewers stressed that information was required concerning dietary habits before the onset of symptoms; and 2 no systemic difference could be detected in the answers to the remainder of the questions; for example, the cancer patients showed no tendency to report eating certain items less frequently than the controls.

The absence of any convincing difference in dietary habits between cancer patients and controls does not necessarily mean that diet has no influence in the aetiology of carcinoma of the stomach. The appropriate questions may not have been asked or the 'recall' method of dietary investigation may be too crude to demonstrate differences that really exist. Tests for reproducibility showed that the patients were unable to give reliable information about the type of cooking utensil or the spread they used on bread before the war, nor about the type of cooking fat they used; other methods will have to be used if it is desired to test the possible effect of these items. If the failure to give reliable information about events before the war was general and the patients were reporting only their recent experience, any important differences in dietary habits in early life between cases and controls might well be obscured. It should not be assumed, however, that this would necessarily invalidate the use of a dietetic history. Changes in the gastric cancer mortality in the U.S.A. suggest that the risk of cancer can be altered substantially, even at advanced ages, so that recent dietetic habits before the onset of illness may be as discriminatory in relation to gastric cancer as recent smoking habits are in another field.

The inadequacy of the dietetic history for providing a complete picture of the individual's food habits has been commented on by other workers. National dietary surveys have substituted the method of asking the housewife how much she spends on different types of food. Heady (1961) has estimated consumption by getting volunteers to weigh their food before each meal for a week. Such methods could be used for a prospective study, but they are inapplicable when a patient is already ill and unable to eat normally. 


\section{SUMMARY}

One hundred consecutive in-patients under 75 years of age in whom a firm diagnosis of carcinoma of the stomach had been made and 200 control inpatients suffering from other non-gastric complaints, matched for age and sex, were subjected to a detailed questionnary concerning their dietary habits. No convincing differences which seem likely to be of aetiological importance were demonstrated. Sixtythree patients were re-interviewed after the lapse of more than three months. The reproducibility of their answers was studied. In certain questions, notably those in which information was requested concerning habits 'before the war', the answers were too variable to be of any scientific value.

We are grateful to Dr. Brian Swynnerton for arranging for us to have access to patients in St. James's Hospital, Balham, and for information about the final diagnoses, and to Mrs. Phoebe M. Paton, A.M.I.A. and Miss K. M. Jones, A.M.I.A. for carrying out the interviews.

\section{REFERENCES}

Doll, R. (1958). Aetiology of cancer of the stomach. In Modern Trends in Gastro-enterology, 2nd series, edited by F. Avery Jones, pp. 53-65. Hoebner, New York.

Dungal, N. (1956). Studies on diet in relation to cancer. A. R. Brit. Emp. Cancer Campgn, 34, 119-120.

- (1961). The special problem of stomach cancer in Iceland. J. Amer. med. Ass., 178, 789-798.
Edwards, F. C., and Edwards, J. H. (1956). Tea-drinking and gastritis. Lancet, 2, 543-545.

Haenszel, W. (1958). Variation in incidence of and mortality from stomach cancer, with particular reference to the United States. J. nat. Cancer Inst., 21, 213-262.

Heady, J. A. (1961). Diets of bank clerks: development of a method of classifying the diets of individuals for use in epidemiological studies. J. roy. statist. Soc., 124, 336-371.

Herbert, W. E., and Bruske, J. S. (1936). Etiology of cancer of the stomach. II. A comparison of the diet and dental conditions of the English and Dutch. Guy's Hosp. Rep., 86, 301-308.

Segi, M., Fukushima, I., Fujisaku, S., Kurihara, M., Saito, S., Asano, K., and Kamoi, M. (1957). An epidemiological study on cancer in Japan. Gann, 48, suppl., April.

Stocks, P. (1957). Cancer incidence in North Wales and Liverpool region in relation to habits and environment. $A$. $R$. Brit. Emp. Cancer Campgn, 35, suppl., pt. 2.

_- and Karn, M. (1933). A co-operative study of the habits, home life, dietary and family histories of $\mathbf{4 5 0}$ cancer patients and of an equal number of control patients. Ann. Eugen. (Lond.), 5, 237-280.

Wynder, E. L., Kmet, J., Dungal, N., and Segi, M. (1963). An epidemiological investigation of gastric cancer. Cancer, 2, 1461-1496.

\section{APPENDIX}

In addition to the items listed in Table III cases and controls were asked how frequently they had eaten the following foodstuffs: Cabbage, red cabbage, sauerkraut, brussels, kale, lettuce, carrots, turnips, cucumber, green peas, dried peas, beets, celery, corn, onions, lamb, pork, ham, bacon, sausage, poultry, eggs, shellfish, grapefruit, lemons, apples, banana, dried fruit, tomato juice, tomato sauce, other sauce, dried beans, broad beans, runner beans, cauliflower, and broccoli. 